\title{
Nitrogen balance in mechanically ventilated obese patients
}

\section{Balanço nitrogenado em pacientes obesos em ventilação mecânica invasiva}

\author{
Raquel Stocker PÉRSICO ${ }^{1}$ iD 0000-0003-0429-4504 \\ Gabriela Corrêa SOUZA ID 0000-0002-3620-4334 \\ Oellen Stuani FRANZOSI ${ }^{3}$ ID 0000-0002-5617-462X \\ Bibiana de Almeida Rubin ROVATI ${ }^{3}$ ID 0000-0003-2911-5998 \\ Zilda Elisabeth de Albuquerque SANTOS² (ID) 0000-0002-0007-0557
}

A B S T R A C T

\section{Objective}

This study aimed to evaluate if the protein intake recommendations for obese critically ill requiring mechanical ventilation are sufficient to promote a positive or neutral nitrogen balance.

\section{Methods}

Cross-sectional study that included 25 obese, $\geq 18$ years old, undergoing mechanical ventilation and who were target to receive high-protein enteral nutrition therapy $(2.0-2.5 \mathrm{~g} / \mathrm{kg}$ ideal body weight). Clinical, nutritional and biochemical variables were analyzed. Nitrogen balance was performed when patient was receiving full enteral nutrition therapy and was classified: positive when intake was greater than excretion; negative when excretion was greater than intake; neutral when both were equal.

\section{Results}

The characteristics of patients evaluated were $64.1 \pm 9.4$ years old, clinical treatment $88 \%$, body mass index $36.5 \pm 5.1 \mathrm{~kg} / \mathrm{m}^{2}$, nitrogen balance $0.3 \mathrm{~g} /$ day $(-5.3$ to $4.8 \mathrm{~g} /$ day), protein intake $2.1 \mathrm{~g} /$ day $(2.0-2.3 \mathrm{~g} / \mathrm{kg})$ ideal body weight. Of individuals analyzed, $52 \%$ showed positive or neutral nitrogen balance with median of $4.23 \mathrm{~g} /$ day 2.41 to $6.40 \mathrm{~g} /$ day) in comparison

1 Universidade Federal do Rio Grande do Sul, Faculdade de Medicina, Programa de Pós-Graduação em Ciências Médicas: Endocrinologia. R. Ramiro Barcelos, n. 2400, Santa Cecília, 90035-003, Porto Alegre, RS, Brasil. Correspondence to: ZEA SANTOS. E-mail: <zesantos@hcpa.edu.br>.

2 Universidade Federal do Rio Grande do Sul, Faculdade de Medicina, Departamento de Nutrição. Porto Alegre, RS, Brasil.

3 Hospital de Clínicas de Porto Alegre, Serviço de Nutrição e Dietética. Porto Alegre, RS, Brasil. Support: Fundo de Incentivo à Pesquisa e Eventos do Hospital de Clínicas de Porto Alegre (18-0006).

How to cite this article

Pérsico RS, Souza GC, Franzosi OS, Rovati BAR, Santos ZEA. Nitrogen balance in mechanically ventilated obese patients. Rev Nutr. 2021;34:e190263. https://doi.org/10.1590/1678-9865202134e190263 
to negative group with median of $-5.27 \mathrm{~g} /$ day $(-10.38$ to $-3.86 \mathrm{~g} /$ day). Adults had higher ratio of negative nitrogen balance $(57.1 \%$ ) than elderly $(44.4 \%)$, with protein intake of 2.0 versus $2.1 \mathrm{~g} /$ day, respectively. No correlation was found between nitrogen balance and variables assessed.

\section{Conclusion}

High-protein enteral nutrition therapy contributed to positive or neutral nitrogen balance for approximately half of obese ventilated individuals. With similar protein intake, elderly showed a higher proportion of positive or neutral nitrogen balance. Nitrogen balance can be influenced by various factors, so further studies are required to identify different protein needs in obese critically.

Keywords: Critical care. Enteral nutrition. Intensive care units. Mechanical ventilation. Nutrition therapy. Obesity.

\section{RE S U M O}

\section{Objetivo}

Avaliar se as recomendações de ingestão proteica para obesos em ventilação mecânica invasiva são suficientes para promover balanço nitrogenado positivo ou em equilíbrio.

\section{Métodos}

Estudo transversal que analisou 25 obesos adultos, em ventilação mecânica invasiva e submetidos à terapia nutricional enteral hiperproteica $(2,0-2,5 \mathrm{~g} / \mathrm{kg}$ de peso ideal). Variáveis clínicas, nutricionais e bioquímicas foram analisadas. 0 balanço nitrogenado foi realizado após a oferta plena da nutrição enteral e classificado como: positivo quando ingestão maior que excreção; negativo quando excreção maior que ingestão; neutro quando ambas foram iguais.

\section{Resultados}

As características dos pacientes avaliados foram idade $64,1 \pm 9,4$ anos, índice de massa corporal 36,5 $55,1 \mathrm{~kg} / \mathrm{m}^{2}$, tratamento clínico 88\%, balanço nitrogenado 0,3g/dia (-5,3 a 4,8g/dia), ingestão proteica 2,1g/dia (2,0-2,3g/kg) de peso ideal. Dos indivíduos analisados, 52\% apresentaram balanço nitrogenado positivo ou neutro com mediana de 4,23g/dia (2,41 a 6,40g/dia), comparado ao grupo com balanço negativo -5,27g/dia (-10,38 a -3,86g/dia). Adultos apresentaram maior proporção de balanço nitrogenado negativo $(57,1 \%)$ do que idosos $(44,4 \%)$, respectivamente, com ingestão proteica semelhante de 2,0 versus 2,1 g/dia. Não foi observada correlação entre balanço nitrogenado e variáveis analisadas.

\section{Conclusão}

A terapia nutricional enteral hiperproteica promoveu um balanço nitrogenado positivo ou neutro em cerca de metade dos obesos em ventilação mecânica invasiva. Com ingestão proteica semelhante, idosos apresentaram maior proporção de balanço positivo ou neutro do que adultos. O balanço nitrogenado pode ser influenciado por diversos fatores e por esse motivo mais estudos são necessários para identificar diferentes necessidades proteicas em pacientes obesos críticos.

Palavras-chave: Cuidados críticos. Nutrição enteral. Unidades de terapia intensiva. Ventilação mecânica. Terapia nutricional. Obesidade.

\section{INTRODUCTION}

In the critical care setting, obesity can contribute to exacerbate ventilatory, cardiovascular, renal and endocrine dysfunctions and pharmacokinetic and pharmacodynamic alterations, leading to an increased metabolic and inflammatory state [1-4]. Due to these metabolic alterations added to physical inactivity, muscle protein synthesis is decreased and muscle mass can be utilized as an energy substrate for gluconeogenesis, leading to excessive proteolysis, a condition associated with higher mortality [3-6].

Nutritional Therapy (NT) recommendations suggest hypocaloric high-protein NT for obese, with the purpose to prevent overfeeding, promote an adequate glycemic control and a positive or neutral Nitrogen Balance (NB), in order to contribute to immune function regulation, wound healing and to decrease the loss of muscle mass [6-12]. 
Studies suggest that high-protein NT contributes to an adequate NB in obese individuals even when in a hypocaloric diet [13-17]. However, these studies were based on small sample sizes, heterogeneous populations, with most individuals categorized as surgical or trauma patients, most of whom received parenteral nutrition, instead of Enteral Nutrition (EN) and were not necessarily submitted to Mechanical Ventilation (MV) $[7,9]$. Considering the characteristics of these studies, there are concerns regarding the generalization of the recommendations to all obese individuals admitted to Intensive Care Units (ICU), including those on MV. The objective of this study is to evaluate if the protein intake recommendations for obese critically ill requiring MV and with hypocaloric EN are sufficient to promote a positive or neutral NB.

\section{METHODS}

Cross-sectional study conducted at the adult ICU of a public teaching hospital. The sample was composed by patients classified as obese according to Body Mass Index (BMI) $\geq 30 \mathrm{~kg} / \mathrm{m}^{2}$, $\geq 18$ years old, on MV and receiving full EN. Between April and August 2018, 70 patients underwent the screening assessment, and after exclusions ( $n=45), 25$ individuals were included on this study. Exclusion criteria were the presence of diarrhea, renal failure (considered as serum creatinine $>2.0 \mathrm{mg} / \mathrm{dL}$, glomerular filtration rate $<30 \mathrm{~mL} / \mathrm{min}$ or renal replacement therapy), hepatic failure (considered as bilirubin levels higher than three times the reference value) and pregnancy.

The following data were analyzed: (a) socio-demographic: age, gender, ethnicity; (b) clinical: diagnosis at admission classified as clinical (respiratory, neurological, cardiovascular or gastrointestinal) or surgical, comorbidities, disease severity (SAPS 3 score - Simplified Acute Physiology Score III and SOFA score - Sequential Organ Failure Assessment Score) (c) nutritional: body weight, height, BMI, time until the onset of NT, protein and caloric intake and adequacy; (d) biochemical: one time 24-hour urinary urea excretion; (e) outcomes: NB, MV time, ICU and hospital time and mortality in the ICU and in the hospital.

Anthropometric data was collected by the staff at the moment of admission, height was measured using a Luft ${ }^{\circledR}$ ruler [18], and weight by using a Hill Rom ${ }^{\circledR}$ in-bed. Subsequently, BMI was calculated and patients were considered class I obesity when BMI $\geq 30 \mathrm{~kg} / \mathrm{m}^{2}$, class II when BMI $\geq 35 \mathrm{~kg} / \mathrm{m}^{2}$ and class III when $\mathrm{BMI} \geq 40 \mathrm{~kg} / \mathrm{m}^{2}$. There were no changes in the routine of care at the unit.

Nutritional therapy protocol utilized stratifies the protein recommendations by BMI degrees [7]. The protein target for BMI 30 to $40 \mathrm{~kg} / \mathrm{m}^{2}$ is $2.0 \mathrm{~g} / \mathrm{kg}$ of Ideal Body Weight (IBW) and for BMl $>40 \mathrm{~kg} / \mathrm{m}^{2}$ is $2.5 \mathrm{~g} / \mathrm{kg}$ IBW, and calorie target for BMI 30 to $50 \mathrm{~kg} / \mathrm{m}^{2}$ is $11-14 \mathrm{Kcal} / \mathrm{kg}$ of Actual Body Weight (ABW) and for BMI $>50 \mathrm{~kg} / \mathrm{m}^{2}$ is $22-25 \mathrm{Kcal} / \mathrm{kg} \mathrm{IBW} \mathrm{[7].} \mathrm{After} \mathrm{defining} \mathrm{individual} \mathrm{calorie} \mathrm{and} \mathrm{protein} \mathrm{targets,} \mathrm{the} \mathrm{amount} \mathrm{of} \mathrm{EN}$ formula is calculated and when protein targets are not reached with enteral formulas, protein supplements are prescribed.

Nutritional therapy was provided by enteral route, using a high-protein polymeric fiber-free formula, with caloric density of $1.5 \mathrm{kcal} / \mathrm{mL}$. During the first 48 hours in ICU, patients were evaluated by ICU physicians regarding to hemodynamic and perfusion conditions to start NT. Beggining of EN was at 10 to $30 \mathrm{~mL} /$ hour and it was increased in 10 to $15 \mathrm{~mL} /$ hour per day until the target is reached. After EN target was reached, protein supplements were included. Protein supplements were constituted by $100 \%$ hydrolyzed whey protein and provided 10-20 grams-dose, given 3 to 5 times a day, as targets prior determined. At the unit, the diet is provided continuously, using a closed system, with nutritional targets computed for 22 hours of feeding, considering a 2-hour break every day for ICU procedures aiming to optimize nutritional adequacy.

Nitrogen Balance was measured one day after the patient achieved the prescribed nutritional target, and was calculated by the equation:

NB (g/day)=nitrogen intake (g/day) - [urinary urea nitrogen (g/day)+4 (g/day)]. 
Considering $4 \mathrm{~g}$ as a constant factor from integumentary, gastrointestinal and insensible losses [19]. NB was defined as positive when nitrogen intake was greater than excretion, negative when excretion was greater than intake and in equilibrium or neutral when both were equal. Nitrogen intake was computed using records from the total amount of enteral diet and protein supplements received during the NB realization day. Urinary urea nitrogen was measured in a one-time 24-hour urine sample, being the urine collected by a urinary catheter every six hours and stored in a refrigerator during the 24 hours of collection. This study only included patients that already had a urinary catheter for clinical purposes. The urine analyses were realized in the clinical analyses laboratory of the hospital using the glutamate dehydrogenase enzymatic kinetic assay method. Electronic medical records were analyzed to assess clinical, demographic, nutritional and biochemical data. The patients were included only after the informed consent was obtained from those legally responsible. This study was approved by the Institutional Ethics Committee under record number \#18-0006.

The study conducted by Dickerson et al. [15] was used to estimate the sample size, considering the mean and standard deviation of daily protein ingestion of $2.3 \pm 0.2 \mathrm{~g} / \mathrm{kg} \mathrm{IBW}$, a standard error of 0.2 , 95\% confidence interval and $10 \%$ of losses, requiring 25 patients for inclusion. SPSS, v.21.0 (IBM ${ }^{\circledR}$ SPSS $^{\circledR}$ Statistics Inc., Chicago, Illinois, United States) was used for statistical analysis with a statistically significant $p$ value of $<0.05$. Mann-Whitney test was performed for comparisons between continuous variables. Correlation analysis between socio-demographic, clinical and nutritional variables and NB were conducted with Spearman's rank correlation. Fisher's exact test was used to association analysis between nutritional variables and outcomes.

\section{RES U L T S}

All included patients were ventilated obese, of which 18 (72\%) were 60 years or older, $22(88 \%)$ were in ICU for clinical treatment and three (12\%) for surgical treatment and were predominantly female and white. Eleven (44\%) patients had class I obesity, nine (36\%) class II, while five (20\%) had class III obesity. All individuals received EN and $22(88 \%)$ received early EN, with onset in up to 48 hours after admission in ICU. Calorie and protein adequacy were higher than 95\% for $21(84 \%)$ and 22 (88\%) individuals, respectively. Calorie intake was 16 (15-17) kcal/kg ABW, data calculated for 24 (96\%) patients because one individual had $\mathrm{BMI}>50 \mathrm{~kg} / \mathrm{m}^{2}$. Median protein ingestion was $2.1 \mathrm{~g} / \mathrm{kg}(2.0-2.3 \mathrm{~g} / \mathrm{kg}) \mathrm{IBW}$. Table 1 describes socio-demographic, clinical and nutritional characteristics of participants.

Median overall NB was $0.3 \mathrm{~g} / \mathrm{kg}$ (-5.3 to $4.8 \mathrm{~g} /$ day), with median time for NB measurement of three (26) days after ICU admission, the period required for NT to reach the target. Considering clinical outcomes, median length of MV was 10 (7-19) days, ICU was 14 (8-23) days and hospital was 28 (19-49) days. Mortality rates in ICU and hospital were of $20 \%$ and $32 \%$, respectively.

Thirteen (52\%) individuals had positive or neutral NB, while twelve (48\%) had negative NB. Table 2 describes comparisons between NB groups. Differences between NB groups for NB and urinary urea excretion were observed. Similar protein intake, age, BMI and SAPS and no differences for secondary outcomes (MV days, ICU and hospital time, mortality in ICU and in hospital) were found.

When stratified by age, negative NB was observed in $44.4 \%$ of elderly ( $\geq 60$ years old) and $57.1 \%$ of adults, without statistical difference. The median NB for elderly and adults were $0.7 \mathrm{~g} / \mathrm{kg}(-6.4$ to $4.5 \mathrm{~g} / \mathrm{kg})$ versus $-3.5 \mathrm{~g} / \mathrm{kg}(-4.7$ to $5.9 \mathrm{~g} /$ day) and median protein intakes were $2.1 \mathrm{~g} / \mathrm{kg}(2.0-2.3 \mathrm{~g} / \mathrm{kg})$ versus $2.0 \mathrm{~g} / \mathrm{kg}$ $(1.9-2.2 \mathrm{~g} / \mathrm{kg}) \mathrm{IBW}$, respectively. 
Table 1 - Socio-demographic, clinical and nutritional characteristics. Hospital de Clínicas de Porto Alegre, Brazil, 2018.

\begin{tabular}{|c|c|c|c|}
\hline Characteristics & Number (\%) & $\mathrm{M} \pm \mathrm{SD}$ & Median (P25-75) \\
\hline Age, years & & $64.1 \pm 9.4$ & \\
\hline Gender, female & $22(88)$ & & \\
\hline Ethnicity, white & $19(76)$ & & \\
\hline \multicolumn{4}{|l|}{ Diagnosis at admission } \\
\hline Respiratory & $9(36)$ & & \\
\hline Neurological & $8(32)$ & & \\
\hline Cardiovascular & $3(12)$ & & \\
\hline Gastrointestinal & $2(8)$ & & \\
\hline Surgical & $3(12)$ & & \\
\hline Oncologic & $2(8)$ & & \\
\hline Abdominal Aortic Aneurism & $1(4)$ & & \\
\hline \multicolumn{4}{|l|}{ Comorbidities } \\
\hline Hypertension & $16(64)$ & & \\
\hline Diabetes & $11(44)$ & & \\
\hline COPD & $5(20)$ & & \\
\hline Neoplasia & $3(12)$ & & \\
\hline Others & $20(80)$ & & \\
\hline Body weight, kg & & & $86.2(79.7-102.0)$ \\
\hline $\mathrm{BMI}, \mathrm{kg} / \mathrm{m}^{2}$ & & $36.5 \pm 5.1$ & \\
\hline Calorie adequacy, \% & & & $104.0(97-106)$ \\
\hline Protein adequacy, \% & & & $102.0(98-103)$ \\
\hline Non-protein calorie/gN2 ratio & & & $49.0(47-55)$ \\
\hline SAPS 3, points & & $66.4 \pm 12.4$ & \\
\hline SOFA, points & & $2.7 \pm 0.8$ & \\
\hline
\end{tabular}

Note: Values expressed as number (\%), M SD or median (P25-75). BMI: Body Mass Index; COPD: Chronic Obstructive Pulmonary Disease; gN2: Grams of nitrogen; SAPS: Simplified Acute Physiology Score; SOFA: Sequential Organ Failure Assessment Score; M: Mean; SD: Standard Deviation.

Table 2 - Comparisons according to nitrogen balance groups. Hospital de Clínicas de Porto Alegre, Brazil, 2018.

\begin{tabular}{|c|c|c|c|c|c|}
\hline \multirow{2}{*}{ Characteristics } & \multicolumn{2}{|c|}{ Positive NB $(n=13)^{*}$} & \multicolumn{2}{|c|}{ Negative NB $(n=12)$} & \multirow{2}{*}{$p$} \\
\hline & $\mathrm{M} \pm \mathrm{SD}$ & Median (P25-75) & $\mathrm{M} \pm \mathrm{SD}$ & Median (P25-75) & \\
\hline$N B, g / d$ & & $4.23(2.41 ; 6.40)$ & & $-5.27(-10.38 ;-3.86)$ & $<0.001$ \\
\hline Age, years & $65.1 \pm 10.3$ & & $63.1 \pm 8.7$ & & NS \\
\hline $\mathrm{BMI}, \mathrm{kg} / \mathrm{m}^{2}$ & $37.1 \pm 6.1$ & & $35.8 \pm 3.7$ & & NS \\
\hline Protein intake, g/kg IBW & $2.09 \pm 0.31$ & & $2.07 \pm 0.22$ & & NS \\
\hline Urinary urea excretion, $\mathrm{g} / \mathrm{d}$ & $24.7 \pm 10.9$ & & $46.8 \pm 13$ & & $<0.001$ \\
\hline SAPS 3, points & $64.5 \pm 12.8$ & & $68.4 \pm 12.2$ & & NS \\
\hline$M V, d$ & & $10(7.5 ; 23)$ & & $10(5.5 ; 18)$ & NS \\
\hline ICU stay, d & & $14(9 ; 26)$ & & $13.5(8.3 ; 24.3)$ & NS \\
\hline Hospital stay, d & & $30(20 ; 50)$ & & $27(18.3 ; 47.5)$ & NS \\
\hline
\end{tabular}

Note: "Positive or Neutral NB. Values expressed as M \pm SD or median (P25-75). BMI: Body Mass Index; IBW: Ideal Body Weight; ICU: Intensive Care Unit; MV: Mechanical Ventilation; NB: Nitrogen Balance; NS: Non-significant; SAPS: Simplified Acute Physiology Score; M: Mean; SD: Standard Deviation.

Patients with class III obesity showed a higher prevalence of positive or neutral NB, being $60.0 \%$ compared to class I with $54.5 \%$, and class II with $44.4 \%$. The median of NB in these groups was $1.66 \mathrm{~g} /$ day (-5.88 to $3.24 \mathrm{~g} /$ day) for class I, $-1.81 \mathrm{~g} /$ day (-6.19 to $4.64 \mathrm{~g} /$ day) for class II, and $4.23 \mathrm{~g} /$ day (-5.93 to $7.22 \mathrm{~g} /$ day) for class III obesity, without statistical difference.

No significant correlation was found between NB and socio-demographic, clinical and nutritional characteristics, as seen in Table 3. No association was found between NB and mortality in ICU and in hospital. 
Table 3 - Correlation between nitrogen balance and associate variables ${ }^{\mathrm{a}}$. Hospital de Clínicas de Porto Alegre, Brazil, 2018.

\begin{tabular}{lcc}
\hline Characteristics & r-value & $p$-value \\
\hline Age, years & -0.005 & NS \\
BMI, kg/m² & 0.237 & NS \\
Protein intake, g/d & 0.163 & NS \\
Non-protein calorie/gN2 & 0.240 & NS \\
SAPS 3, points & -0.194 & NS \\
SOFA, points & 0.028 & NS \\
MV, d & 0.176 & NS \\
ICU stay, d & 0.147 & NS \\
Hospital stay, d & -0.104 & \\
\hline
\end{tabular}

Note: a'Spearman's Rank Correlation. $n=25$ BMI: Body Mass Index; ICU: Intensive Care Unit; MV: Mechanical Ventilation; NS: Non-significant; SAPS: Simplified Acute Physiology Score; SOFA: Sequential Organ Failure Assessment Score.

\section{DISCUSSION}

All individuals received high-protein enteral feeding, with a median of $2.1 \mathrm{~g} / \mathrm{kg} \mathrm{IBW}$, providing positive or neutral NB for approximately half of obese individuals requiring MV. Analyzing by groups, positive or neutral versus negative NB, a difference was found for NB and urinary urea excretion, but no differences were found for protein and calorie intake and adequacy, and SAPS 3 score. No significant correlation was found between NB and assessed variables. No association was found between NB and the outcomes assessed, and we hypothesize that it could be explained by the restricted number of patients in our sample and maybe due to its heterogeneity. Patients had different obesity degrees and diagnoses at admission, also, even the most of them were admitted for clinical purposes, three were surgical and three had oncologic disease, situations that can influence the protein needs.

Catabolism is exacerbated by critical illness, specially protein catabolism that contributes to loss of muscle mass, with loss proportional to disease severity [20]. Considering that stressed obese commonly are insulin resistant, this group may have a higher protein turnover and greater catabolism [21]. Some studies showed that a greater adequacy in protein and calorie targets is associated with greater outcomes for ICU patients, as reported by Nicolo et al. [22], where a protein adequacy $>80 \%$ independent of calorie intake had association with reduced mortality rates. In our study, protein adequacy was greater than $95 \%$ for most of the sample, but even while receiving adequate protein intake no difference was found between positive and negative NB groups in relation to mortality rate.

Recommendations suggest that obese ICU patients can achieve adequate NB receiving high-protein NT, even when receiving hypocaloric diet [7]. However, these studies were conducted with populations of obese who were mostly classified on admission in ICU as surgical or trauma, and who were predominantly administered parenteral nutrition, with no difference in NB values found when compared to patients who received hypocaloric versus eucaloric high-protein NT [13,23,24].

Recently studies demonstrated that hypocaloric high-protein NT is safe to obese critically ill, including sarcopenic obese $[6,11,21,25]$. A subset analysis of pre-morbid obese critically ill found that individuals with hypocaloric vs normocaloric NT, but with similar protein intake, had no statistical difference in relation to ICU and hospital time, mortality and infection rates [26].

In our sample $52 \%$ had positive or neutral NB, being NB 0.3 (-5.3 to 4.8$) \mathrm{g} /$ day, with median protein intake of $2.1 \mathrm{~g} / \mathrm{kg} \mathrm{IBW}$ receiving enteral feeding. A study with 25 mechanically ventilated obese patients found a NB of $-2.3 \pm 5.1 \mathrm{~g} /$ day, but protein requirements met $25 \%$ of target [17]. Forty obese critically ill 
subjects receiving hypocaloric versus eucaloric EN, with $1.58-1.99 \mathrm{~g} / \mathrm{kg}$ IBW of protein, found NB close to neutral, though all NB had negative values in the first two weeks of stay at ICU [14]. However, obese critically ill with traumatic injury showed similar results to our study in relation to positive or neutral NB, being $55 \%$ and $56 \%$ for older and younger individuals, respectively $[15,16]$. In some specific situations, critically ill obese may need higher amounts of protein compared to nonobese, as described in two studies that evaluated patients in extracorporeal membrane oxygenation, whereas obese groups had a more pronounced negative NB $[27,28]$.

Literature suggests that elderly individuals may have a decline in anabolic response and difficulty mobilizing body fat stores as energy sources, conditions that lead to an increase consumption of muscle mass $[11,29]$. Our analysis showed that adults had higher rates of negative NB compared to elderly subjects. In a similar way, a study that compared elderly obese patients to adult ones, showed that adults had greater values for NB 3.44 versus $0.2 \mathrm{~g} /$ day, with similar protein ingestion of $1.6-1.7 \mathrm{~g} / \mathrm{kg}$ adjusted body weight [29]. However Dickerson et al showed that in trauma patients NB values were lower, but not statistically significant, between adults (-4.9d/day) in comparison to elderly $(-3.2 \mathrm{~g} /$ day) with similar protein intake of $2.3 \mathrm{~g} / \mathrm{kg} \mathrm{IBW}$ of protein [15].

Nitrogen balance may be influenced by various factors and it has the aim to help in evaluation of protein intake adequacy to individual's needs. Although our sample consisted solely by obese patients undergoing MV, this study has some limitations. NB was measured only once, at the early stage of acute injury and sample was not stratified by severity, thus our results may reflect various metabolic states, making it difficult to interpret protein requirements and adequacy at different disease severities and stages. NB was not analyzed according to different degrees of obesity and number of comorbidities, which can influence in protein needs.

\section{CONCLUSION}

Our data suggest that a daily protein intake around $2.1 \mathrm{~g} / \mathrm{kg} \mathrm{IBW}$ was able to promote positive or neutral NB in $52 \%$ of the population of obese individuals undergoing MV, enteral NT and predominantly receiving clinical treatment. Studies with large sample size, serial NB measures in the first ICU week, severity stratification, and analysis according to different obesity degrees are required in order to identify different protein needs of obese critically ill patients undergoing MV.

\section{CONTRIBUTORS}

All authors have contributed to the conception, design, analysis and interpretation of the data and agree to be fully accountable for ensuring the integrity and accuracy of the work, and read and approved the final manuscript.

\section{REFERENCES}

1. Hurt RT, Frazier TH, McClave SA, Kaplan LM. Obesity epidemic: overview, pathophysiology, and the intensive care unit conundrum. J Parenter Enteral Nutr. 2011;35(55):4-13. https://doi.org/10.1177/0148607111415110

2. Lewandowski K, Lewandowski M. Intensive care in the obese. Best Pract Res Clin Anaesthesiol. 2011;25(1):95-108. https://doi.org/10.1016/j.bpa.2010.12.003

3. Patel JJ, Rosenthal MD, Miller KR, Codner P, Kiraly L, Martindale RG. The critical care obesity paradox and implications for nutrition support. Curr Gastroenterol Rep. 2016;18(9):1-8. https://doi.org/10.1007/s11894-016-0519-8 
4. Selim BJ, Ramar K, Surani S. Obesity in the intensive care unit: risks and complications. Hosp Pract. 2016;44(3):146-56. https://doi.org/10.1080/21548331.2016.1179558

5. Port AM, Apovian C. Metabolic support of the obese intensive care unit patients: a current perspective. Curr Opin Clin Nutr Metab Care. 2010;13(2):184-91. https://doi.org/10.1097/MCO.0b013e328335f1e6

6. Tieland M, Van Dronkelaar C, Boirie Y. Sarcopenic obesity in the ICU. Curr Opin Clin Nutr Metabol Care. 2019;22(2):162-6. https://doi.org/10.1097/MC0.0000000000000547

7. McClave SA, Taylor BE, Martindale RG, Warren MM, Johnson DR, Braunschweig C, et al. Guidelines for the provision and assessment of nutrition support therapy in the adult critically ill patient: Society of Critical Care Medicine and American Society for Parenteral and Enteral Nutrition. J Parenter Enteral Nutr. 2016;40(2):159-211. https://doi. org/10.1177/0148607115621863

8. Dickerson RN. Nitrogen balance and protein requirements for critically ill older patients. Nutrients. 2016;8(4):226. https://doi.org/10.3390/nu8040226

9. Singer $P$, Blaser AR, Berger MM, Alhazzani W, Calder PC, Casaer MP, et al. ESPEN guideline on clinical nutrition in the intensive care unit. Clin Nutr. 2019;38(1):48-79. https://doi.org/10.1016/j.clnu.2018.08.037

10. Weijs PJM, Stapel SN, Groot SDW, Driesen RH, Jong E, Girbes ARJ, et al. Optimal protein and energy nutrition decreases mortality in mechanically ventilated, critically ill patients: a prospective observational cohort study. J Parenter Enteral Nutr. 2012;36(1):60-8. https://doi.org/10.1177/0148607111415109

11. Dickerson RN. Protein requirements during hypocaloric nutrition for the older patient with critical illness and obesity: an approach to clinical practice. Nutr Clin Practice. 2020;35(4):617-26. https://doi.org/10.1002/ncp.10501

12. Singer P. Protein metabolism and requirements in the ICU. Clinical Nutrition Espen. 2020;38:3-8. https://doi. org/10.1016/j.clnesp.2020.03.026

13. Choban PS, Burge JC, Scales D, Flancbaum L. Hypoenergetic nutrition support in hospitalized obese patients: a simplified method for clinical application. Am J Clin Nutr. 1997;66(3):546-50. https://doi.org/10.1093/ajcn/66.3.546

14. Dickerson RN, Boschert KJ, Kudsk KA, Brown RO. Hypocaloric enteral tube feeding in critically ill obese patients. Nutrition. 2002;18(3):241-6. https://doi.org/10.1016/s0899-9007(01)00793-6

15. Dickerson RN, Medling TL, Smith AC, Maish III GO, Croce MA, Minard G, et al. Hypocaloric, high-protein nutrition therapy in older vs younger critically ill patients with obesity. J Parenter Enteral Nutr. 2013;37(3):342-51. https://doi. org/10.1177/0148607112466894

16. Dickerson RN. Hypocaloric, high-protein nutrition therapy for critically ill patients with obesity. Nutr Clin Pract. 2014;29(6):786-91. https://doi.org/10.1177/0884533614542439

17. Vest MT, Newell E, Shapero M, McGraw P, Jurkovitz C, Lennon SL, et al. Energy balance in obese, mechanically ventilated intensive care unit patients. Nutrition. 2019;66:48-53. https://doi.org/10.1016/j.nut.2019.02.021

18. Luft VC, Beghetto MG, Castro SMJ, Mello ED. Validation of a new method developed to measure the height of adult patients in bed. Nutr Clin Pract. 2008;23(4):424-8. https://doi.org/10.1177/0884533608321212

19. Dickerson RN. Using nitrogen balance in clinical practice. Hospital pharmacy. 2005;40(12):1081-5. https://doi. org/10.1177/001857870504001210

20. Puthucheary, ZA, Rawal J, McPhail M, Connolly, B, Ratnayake G, Chan P, et al. Acute skeletal muscle wasting in critical illness. Jama. 2013;310(15):1591-600. https://doi.org/10.1001/jama.2013.278481

21. Dickerson RN, Patel JJ, McClain CJ. Protein and calorie requirements associated with the presence of obesity. Nutr Clin Pract. 2017;32(1Suppl):86S-93S. https://doi.org/10.1177/0884533617691745

22. Nicolo M, Heyland DK, Chittams J, Sammarco T, Compher C. Clinical outcomes related to protein delivery in a critically ill population: a multicenter, multinational observation study. J Parenter Enteral Nutr. 2016;40(1):45-51. https://doi.org/10.1177/0148607115583675

23. Dickerson RN, Rosato EF, Mullen JL. Net protein anabolism with hypocaloric parenteral nutrition in obese stressed patients. Am J Clin Nutr. 1986;44(6):747-55. https://doi.org/10.1093/ajcn/44.6.747

24. Burge JC, Goon A, Choban PS, Flancbaum L. Efficacy of hypocaloric total parenteral nutrition in hospitalized obese patients: a prospective, double-blind randomized trial. J Parenter Enteral Nutr. 1994;18(3):203-7. https://doi. org/10.1177/0148607194018003203

25. Dickerson RN. Metabolic support challenges with obesity during critical illness. Nutrition. 2019;57:24-31. https:// doi.org/10.1016/j.nut.2018.05.008 
26. Charles EJ, Kane WJ, Willcutts KF, O'Donnell KB, Petroze RT, Sawyer RG. Hypoenergetic feeding does not improve outcomes in critically ill patients with premorbid obesity: a post hoc analysis of a randomized controlled trial. Nutr Res. 2020;74:71-7. https://doi.org/10.1016/j.nutres.2019.11.011

27. Pelekhaty S, Galvagno SM, Hochberg E, Herr DL, Lantry JH, Kon ZN, et al. Nitrogen balance during venovenous extracorporeal membrane oxygenation support: preliminary results of a prospective, observational study. J Parenter Enteral Nutr. 2018;44(3):548-53. https://doi.org/10.1002/jpen.1176

28. Pelekhaty SL, Galvagno SM, Lantry JH, Dolly KN, Herr DL, Kon ZN, et al. Are current protein recommendations for the critically ill adequate for patients on VV ECMO: experience from a high-volume center. J Parenter Enteral Nutr. 2019;44(2):220-6. https://doi.org/10.1002/jpen.1602

29. Liu KJM, Cho MJ, Atten MJ, Panizales E, Walter R, Hawkins D, et al. Hypocaloric parenteral nutrition support in elderly obese patients. Am Surgeon. 2000;66(4):394-400.

Received: January 27, 2020

Final version: December 22, 2020

Approved: February 3, 2021 